\title{
マンガン鉱石の溶融カリウム塩分解によるマンガン $(\mathbf{V})$ 酸カリウム生成反応の基礎的研究 ${ }^{1)}$
}

\author{
（1974 年 7 月 29 日 受 理）
}

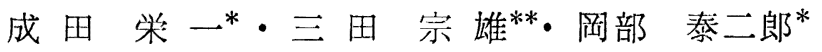

マンガン鈗石を水酸化カリウムー硝酸カリウム系溶融塩で分解し，マンガン（V）酸カリウムを生成す る反応について $200 \sim 240^{\circ} \mathrm{C}$ の温度域で速度論的検討を行なった。

$$
2 \mathrm{MnO}_{2}+6 \mathrm{KOH}+\mathrm{KNO}_{3}=2 \mathrm{~K}_{3} \mathrm{MnO}_{4}+\mathrm{KNO}_{2}+3 \mathrm{H}_{2} \mathrm{O}
$$

反応の進行とともに鈗石の粒径が縮小していくことから，この反応を溶解型コア・モデルに基づいて 検討すると，酸化率曲線は化学反応律速の速度式

$$
1-(1-x)^{1 / 3}=k l
$$

に適合することが見いだされた。ここで， $x$ はマンガン酸化率， $k$ は定数， $t$ は反応時間，である。 Arrhenius プロットから得られる見かけの活性化エネルギーはインド産鈗石の場合 $36 \mathrm{kcal} / \mathrm{mol}$ であり, 西アフリカ・ガボン産鉱石についてもほぼ同じ結果が得られた。

さらに，実用的見地からマンガン鉱石，水酸化カリウム括よび硝酸カリウムの各種配合比率の配合物 について温度を変えて加熱処理を行ない，マンガン（V)酸カリウム生成の好適条件を検討した。マンガ ン酸化率が $95 \%$ 以上であって，かつ反応系が作業性のよい均一な流動性をたもつ条件として，アルカ リモル比 $\left(\mathrm{KOH} / \mathrm{MnO}_{2}\right)=5$, 酸化剂モル比 $\left(\mathrm{KNO}_{3} / \mathrm{MnO}_{2}\right)=1$, 温度 $300 \sim 350^{\circ} \mathrm{C}$, 時間 $1 \sim 2$ 時間が 得られた。

\section{1 鍺 言}

過マンガン酸カリウムの製造に和ける中間体であるマンガン （U）酸カリウムの製造には，従来マンガン鉱石（軟マンガン鉱） にアルカリとして濃厚水酸化カリウム溶液を添加し，空気または 酸素を送りながら回転炉中で $200 〜 350^{\circ} \mathrm{C}$ にバイ暁するアルカリ 酸化バイ烧法2がー般に行なわれている。

しかしながら，この間に行なわれるマンガン(V)酸カリウム生 成反応は固体 (鉱石)，融体 (KOH) 特よび気体（酸素）の相互 の界面学通じて行なわれ，しかも反忍の進行沉れてこれらの接 触状態も複雓に変化して反応完結が困㛹で㐫るため, 多くの場合 鉱石中の $\mathrm{MnO}_{2}$ 成分のマンガン $(\mathrm{V})$ 酸カリウムへの酸化は荤く， かつ低調（約 90\%）である。また，その反梳機構は明らかにされ て扣らず，マンガン(V)酸カリウムの生成を経由するともいわれ ているが碓かではない。さらに，このち法は多数の大規模な装置 を必要とするため多類の費用を要し，操作条件の管理がむずかし いなど耀点を有して捄り，技術的改善の余地を残している。

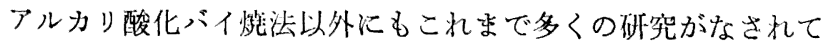

1）この報文を“マンガンのオキソ酸アルカリの製造に関する 研宛 (第 1 報)”とする.

* 東北大学工学部応用化学科, 980 仙台市荒巻字青葉

** 日本化学工業株式会社研究部, 136 東京都江東区龟戸

2) Kirk-Othmer, "Encyclopedia of Chemical Technology", John Wiley \& Sons, Inc., New York (1964) 2 nd Ed., Vol. 13, p. 35 .
いるが，より多くの長所を有する工業的製法はほとんどなく，多 量の水酸化カリウム含水融体により処理する Carus 社の特許》 が注目されているにすぎない。

これに対して著者らはマンガン鉱石の水酸化カリウム融体によ る処理法が若干の技術的問題を克服すれば従来法にまさる有利な 新規製造法になり得るとの観点に立ち研究した結果，マンガン鉱 石を水酸化カリウムにある程度の硝酸カリウムを添加した溶融塩 で処理することにより容易にマンガン $(\mathrm{V})$ 酸カリウムになること が見いだされた。この反応は固体(銨石) と融体 $\left(\mathrm{KOH}, \mathrm{KNO}_{3}\right)$ か らなる均質なスラリー状態で行なわれるため速く，装置および操 作の面でも有利である。そこで，マンガン $(\mathrm{V})$ 酸カリウムを経由 するマンガンのオキり酸アルカリの工業的製造法を想定し，その 第 1 段階としてマンガン (V)酸カリウム生成反心伛ついて基磷的 研究を行なった。

本研究は, マンガン鉱石の水酸化カリウム一硝酸カリウム系溶 融监処理によるマンガン $(\mathrm{V})$ 酸カリウム生成反応について，まず 速度論的実験を行なってその反応様式および速度を検討し，つい で実用的な見地から好適条件の探索を行なったものである。

な扰，マンガン $(\mathrm{V})$ 酸カリウムの合成法として JezowskaTrzebiatowska ら゙)がアルカリ融体中で酸化肪として硝酸カリウ

3) U. S. P., 2, 940, 821, 2, 940, 822, 2, 940, 823 (1960) ; 日特 公 昭 35-6545.

4) B. Jezowska-Trzebiatowska, J. Nawojska, M. Wrońska, Roczniki Chem., 25, 405(1951). 
ムを用いる方法を報告しているが，これは対象が 2 琎のマンガン であり，工業的見地から研究されたものではない。

\section{2 実 験 方 法}

\section{1 試 料}

速度論的実騃に使用したマンガン鉱石は主としてインド産の軟 マンガン鉱で, この他に西アフリカ・ガボン産のものも用いた。

インド鉱の組成は $\mathrm{MnO}_{2} 87.6 \%, \mathrm{Fe}_{2} \mathrm{O}_{3} 5.2 \%, \mathrm{Al}_{2} \mathrm{O}_{3}$ 1.4\%， $\mathrm{SiO}_{2} 1.3 \%$ であり, 比重は 4.06 であった。

本実験では，これらの鉱石を粉砕し，所定の粒度に調整したの ら水洗・乾燥して使用した。

好適条件の探索に使用したマンガン鉱石はインド産の軟マンガ ン鉱で, 钽粉砕し 150 メッシュ98\% パスの粒度として用いた。 そのマンガン含有率は $\mathrm{MnO}_{2} 76.8 \%$, 比重は 4.04 であった。

水酸化カリウム, 硝酸カリウムはいずれも市販の一級試薬であ り，その純度は水酸化カリウムが $83.0 \%$ ，硝酸カリウムが 99.9 \%である。たたし，吸収スペクトルの测定に用いた試薬はすべ て市肘の特級試薬である。

\section{2 実験装置および操作}

反応装置を図 1 に示す。反応器は内容積約 $300 \mathrm{ml}$ のステンレ ス（SUS 27）製でかきまぜ器を有する。

これを電気炉に設置して Pt-Pt・Rh 熱電対を接続した電位差計 式自動温度調節計により所定温度の $\pm 1^{\circ} \mathrm{C}$ となるように制御し た。

速度論的実験は，水酸化カリウム一硝酸カリウムの混合塩 $150 \mathrm{~g}$ を反応器に入れて窒素ガス雾囲気中で昇温し溶融させ，か きまぜを行ないながら所定温度に約 1 時間保持して温度を安 定させたのち所定量の鉱石を添加して反応を開始した。一定時間 ごとに生成物の試料を採取してマンガン酸化率を測定し, 鉱 石添加以後の時間経過にともなら反応の推移を調べた。ただし， 試料の採取は鉄棒を反応系（融体）に㨀入して取り出し，鉄棒 に付着・凝固した生成物をただちに削り取ることによって行なっ た。

好適条件探索の実験に扰いては，マンガン鉱石をあらかじめ混 合カリウム塩といっしょに反応器に入れてから昇温した。これは 速度論的実験の場合にくらべて鉱石の配合量が多くなるため, 鉣

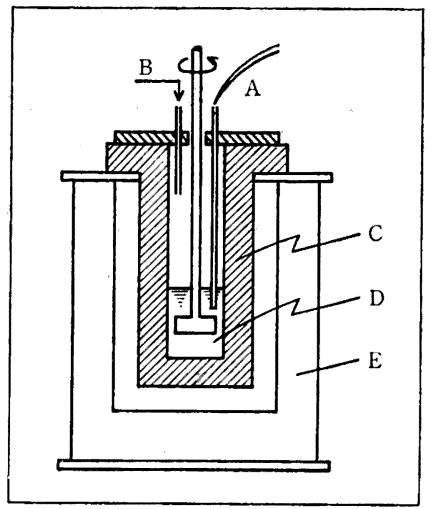

Fig. 1 Apparatus

A : Thermocouple, $B: \mathrm{N}_{2}$-gas inlet, $\mathrm{C}:$ Reaction vessel (SUS 27), D : Molten salts, E : Electric furnace
石を融体に添加すると温度が急変したり，融体が飛散したり，さ らにマンガン鉱石が膨潤して反応系が粘稠化してしまうためであ る。この場合, 昇温して所定温度に到寈した時点を反応開始とみ なした。

\section{3 分析方法}

5 価マンカン量：速度論的実験に扣いては，採取した生成物試 料約 $1 \mathrm{~g}$ を精科し，50\% 水酸化カリウム溶液 $30 \sim 40 \mathrm{ml}$ に浸漬 して塩類を溶解・抽出し, 沪過・洗浄を行なって試料溶液を得 る。

この試料溶液を水で希釈し，硫酸（1+1）を加えて酸性にした のち $3 \%$ 過酸化水素水を加えてマンガンを 2 価まで還元する。こ の溶液の一部を採取し, 約 $0.5 \mathrm{~g}$ の過ヨウ素酸カリウムを加えて 加熱し過マンガン酸カリウムに酸化して発色させる。ついでその 比色定量により可溶性の 5 価マンガン量を求め, 次式によりマン ガン酸化率を算出する。

$$
\text { マンガン酸化率 }(\%)=\frac{\text { 試料溶液中の } 5 \text { 価マンガン量 }}{\text { 試料中の全マンガン量 }} \times 100
$$

ただし, 試料中の全マンガン量は鉣石, 水酸化カリウム, 硝酸 カリウムなどの配合物が均一に混在しているものとみなして算出 するが, 溶融にさいして $5.8 \%$ 程度の重量減少が認められるので その補正をほどこす。

好適条件探索の実験においても, 分析方法は上記の方法とほぼ 同じであるが，マンガン酸化率の算出にさいしては試料中の未反 応の 4 価マンガン量す測定し,

(試料中の全マンガン量) =

$$
\text { ( } 5 \text { 価マンガン量) }+ \text { ( } 4 \text { 価マンガン量) }
$$

とする。

吸収スペクトル測定 : 吸光度の測定は日立 101 型分光光電光度 計により層長 $10 \mathrm{~mm}$ の石英製セルを用いた。

全窒素量 : 生成物試料を温水に溶解し，不溶残留物を沪別した 沪液中の窒素酸化物をデバルダ合金法により還元して全窒素の量 をアンモニアとして求め, 全空素量 (T.N) に換算して表わす。

亜硝酸根量：生成物試料を $10 \%$ 水酸化カリウム溶液に溶解し， 緑色が消えるまで $3 \%$ 過酸化水素水を過剩にならないように加元 てマンガン(U)酸カリウム（不均化反応によって生したたの）を 二酸化マンガンとして沈殿させる。不溶残留物を沪別した沪液中 の亜硝酸根をザルッマン法により比色定量して求める。

\section{3 実験結果と考察}

\section{1 速度論的検討}

3.1 .1 生成物の吸収スペクトル：150〜170 メッシュに粒度調 獘したインド産マンガン鉱石 $2.5 \mathrm{~g}$ を $\mathrm{KOH}-\mathrm{KNO}_{3}$ 系溶融塩 $\left(\mathrm{KNO}_{3} 15 \mathrm{~mol} \%\right) 150 \mathrm{~g}$ に添加し， $220^{\circ} \mathrm{C}$ でかきまぜ速度 300 $\mathrm{rpm}$ にして 3 時間反応させて得た生成物を試料とした。試料の一 部を $50 \%$ 水酸化カリウム溶液に溶解し, 不溶性残留物を沪则し たのち測定した吸収スペクトルを図 2 に示す。

$\mathrm{MnO}_{4}{ }^{2-}, \mathrm{MnO}_{4}{ }^{3-}$ はそれぞれ既往の文献 ${ }^{536)}$ に基ついて調製した ものの吸収スペクトルであるが，生成物の吸収スペクトルは Mn・ $\mathrm{O}_{4}{ }^{3-}$ のとれに一致していることがわかる。

5) R. Scholder, H. Waterstradt, Z. Anorg. Allg. Chem., 277, 172(1954).

6) H. Lux, Z. Naturforschung, 1, 281(1946). 


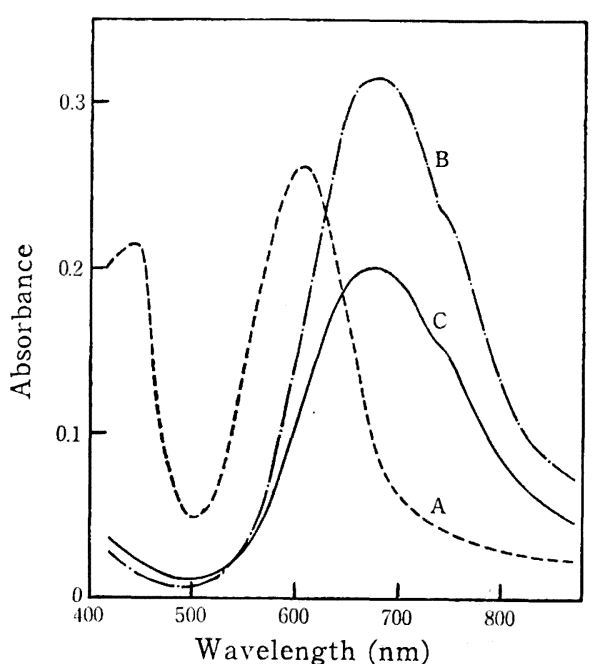

Fig. 2 Absorption spectra of $\mathrm{MnO}_{4}{ }^{2-}, \mathrm{MnO}_{4}{ }^{3-}$, and reaction product
A : $\mathrm{MnO}_{4}{ }^{2-}\left(2.0 \times 10^{-4} \mathrm{~mol} / \mathrm{l}\right)$
$\mathrm{B}: \mathrm{MnO}_{4}{ }^{3-}\left(4.0 \times 10^{-4} \mathrm{~mol} / \mathrm{l}\right)$
C : Reaction product (Mn : $2.5 \times 10^{-4} \mathrm{~mol} / \mathrm{l}$ )

二酸化マンガンと水酸化カリウムの反応については，アルカリ モル比 $\left(\mathrm{KOH} / \mathrm{MnO}_{2}\right)$ が 3 以上, 酸素䨌因気中, $500^{\circ} \mathrm{C}$ の条件で マンガン $(\mathrm{V})$ 酸カリウムが比較的容易に生成することが知られて (る7)8)。ここでは $150 \mathrm{~g}$ の溶融塩に対して少量 $(2.5 \mathrm{~g}$ 程度) のマンガン鉱石を加えていることからアルカリモル比はきわめて 大きく，反応は（1）式のように進行しマンガン (V)酸カリウム が生成するものと考えられる。

$$
2 \mathrm{MnO}_{2}+6 \mathrm{KOH}+\mathrm{KNO}_{3}=2 \mathrm{~K}_{3} \mathrm{MnO}_{4}+\mathrm{KNO}_{2}+3 \mathrm{H}_{2} \mathrm{O}
$$

またここでは硝酸カリウムを酸化剂として用いているので反応 の進行にともなって融体中に雨硝酸カリウムが共存してくる。溶 融硝酸塩中では水酸化アルカリが存在すれば $\mathrm{MnO}_{4}{ }^{3-}$ が安定に存 在し得ることが報告されている9 。溶融亜硝酸塩中では準安定状 態で存在し， $\mathrm{O}_{2}{ }^{2-}$ が共存すればきわめて安定化することが報告さ れている6) 10)が，ここでは鉙石涯加量が少量であるため鉱石を酸 化して生じる西硝酸カリウムも少量であり，しかも多量の水酸化 カリウム, 硝酸カリウムが存在するので亚硝酸カリウムによるマ ンガン ( V ) 酸カリウムの睘元は起こらないものと考光られる。

生成物を水または希薄アルカリ溶液に浸漬するとマンガン溶解 率は，50\% 水酸化カリウム溶液に浸漬したときの $1 / 2$ になる。 これは生成したマンガン $(\mathrm{V})$ 酸カリウムが水または希薄アルカリ 溶夜中では不安定で，ただちに（2）式のように不均化反応を起 こしてマンガン $(\mathrm{V})$ 酸カリウムと二酸化マンガンになり, 前者だ けが溶解するからである。この場合, 得られる吸収スペクトルは 図 2 の $\mathrm{MnO}_{4}^{2-}$ に相当する。

7) R. Scholder, D. Fischer, H. Waterstradt, Z. Anorg. Allg. Chem., 277, 234(1954).

8) K. Teske, H. A. Lehmann, Chem. Tech., 17, 493(1965).

9) R. M. Bennett, O. G. Holmes, Can. J. Chem., 41, 108 (1963).

10) R. B. Temple, G. W. Tickett, Aust. J. Chem., 25, 655 (1972).

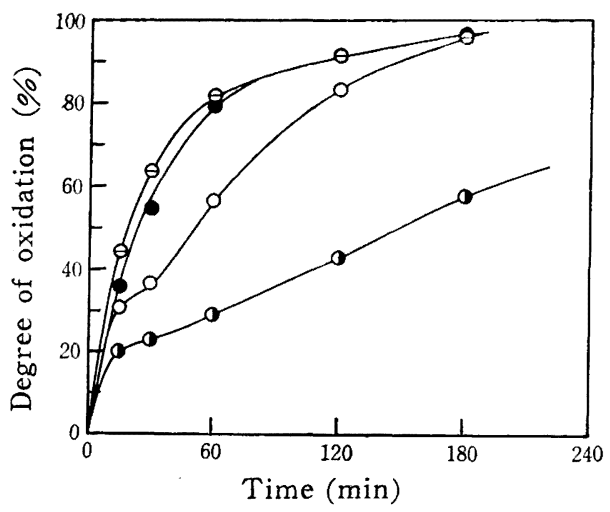

Fig. 3 Effect of ore amount

$\mathrm{KOH}-\mathrm{KNO}_{3}$ salts amount $: 150 \mathrm{~g}$

$\mathrm{KNO}_{3}$ concentration : $15 \mathrm{~mol} \%$

Ore grain size : $150 \sim 170$ mesh

Temperature : $220^{\circ} \mathrm{C}$, Agitation : $300 \mathrm{rpm}$ Ore amount $(\mathrm{g})-$

$$
\ominus: 1.0, \bigcirc: 1.5, \bigcirc: 2.5, \bigcirc: 5.0
$$

$$
2 \mathrm{~K}_{3} \mathrm{MnO}_{4}+2 \mathrm{H}_{2} \mathrm{O}=\mathrm{K}_{2} \mathrm{MnO}_{4}+\mathrm{MnO}_{2}+4 \mathrm{KOH}
$$

\section{1 .2 反応条件の選択}

（1）鉱石添加量の影響：150〜170メッシュに粒度調整した インド産マンガン鉱石の添加量を $\mathrm{KOH}-\mathrm{KNO}_{3}$ 系溶融塩 $\left(\mathrm{KNO}_{3}\right.$ $15 \mathrm{~mol} \%) 150 \mathrm{~g}$ に対して $1.0,1.5,2.5,5.0 \mathrm{~g}$ と変え, かき まぜ速度 $300 \mathrm{rpm}$, 温度 $220^{\circ} \mathrm{C}$ で反応を行なった結果を図 3 に 示す。

添加量 $1.0,1.5 \mathrm{~g}$ の場合は反応速度への影響に大きな差が認 められないが，2.5，5.0 g では反応速度は低下する。これはマン ガン鉱石と溶融塩とくに酸化剂としての硝酸カリウムとの相対モ ル比の相違によるものと考えられる。固・液系の反応速度を調べ るためには液側濃度が反応を通して一定とみなせる程度の鉱石量 を使用することが必要であり，換言すれば反応速度は鉱石量に影 響されない条件での測定が要求される。

因 3 から添加量 $1.5 \mathrm{~g}$ 以下が望ましいことがわかるが, この条 件では分析誤差がかなり増してくる。そこで添加量を $2.5 \mathrm{~g} に$ 定 め, 以後の実験を通じて一定とした。この場合，（1）式によれば アルカリモル比 $=69.0$, 酸化剂モル比 $=12.2$ となる。

（2）溶融カリウム塩組成の影響：150〜170メッシュのイン ド産マンガン鈗石 $2.5 \mathrm{~g}$ を $\mathrm{KNO}_{3}$ 含有率の異なる $\mathrm{KOH}-\mathrm{KNO}_{3}$ 系溶融塩 $150 \mathrm{~g}$ に添加し, $300 \mathrm{rpm}, 220^{\circ} \mathrm{C}$ で反応させたときの 結果を図 4 に示す。

これからわかるように反応速度は $\mathrm{KNO}_{3}$ 含有率 $15 \mathrm{~mol} \%$ の ときに最大值を示している。ここで $15 \mathrm{~mol} \%$ 以上において反 㐫速度が小さくなることは, 前に述べた鉱石中の $\mathrm{MnO}_{2}$ 成分に 対する酸化剤としての硝酸カリウムの量的関係では説明できな い。むしろ本分解反応を, 水酸化カリウムによるマンガン鉱石の 構造破壊, すなわち酸・塩基反応と硝酸カリウムによる酸化反応 の二つにわけてみると，それぞれの作用において水酸化カリウム， 硝酸カリウムはたがいに溶媒とみなせるので，そのためにある特 定の組成（ここでは $\mathrm{KNO}_{3}$ 含有率 $15 \mathrm{~mol} \%$ ）に打いて反応速度 がもっとも大きくなるものと考えられる。

（3）かきまぜ速度の影鄰：150１70 ×ッシュのインド産鉱 


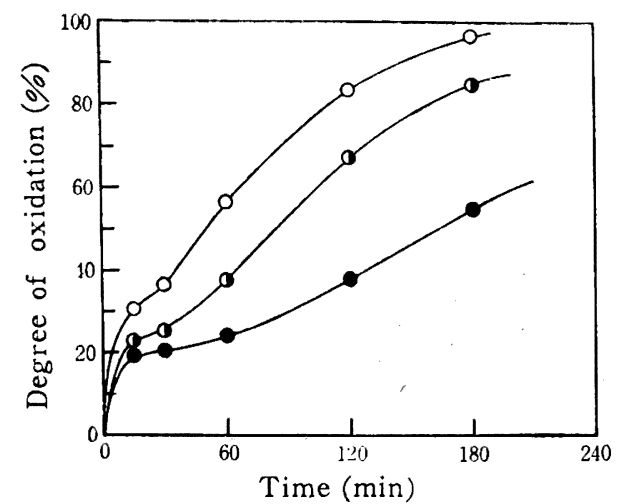

Fig. 4 Effect of $\mathrm{KNO}_{3}$ concentration

$\mathrm{KOH}-\mathrm{KNO}_{3}$ salts amount : $150 \mathrm{~g}$

Ore grain size : $150 \sim 170$ mesh

Temperature $: 220^{\circ} \mathrm{C}$, Ore amount $: 2.5 \mathrm{~g}$

Agitation : $300 \mathrm{rpm}$

$\mathrm{KNO}_{3}$ concentration $(\mathrm{mol} \%)-$

$: 7.5, \bigcirc: 15, \bigcirc: 30$

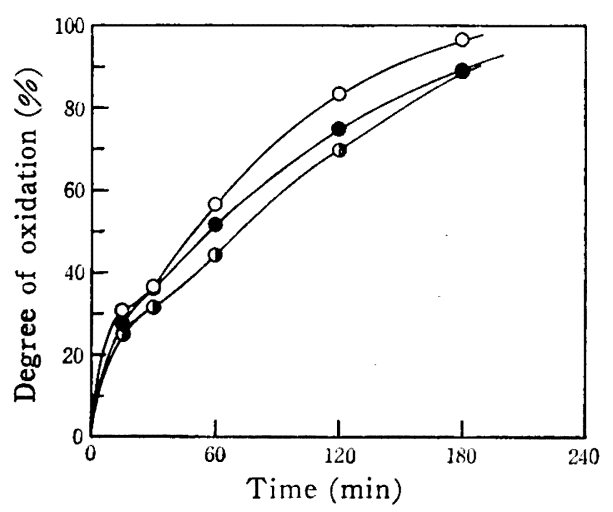

Fig. 5 Effect of agitation

$\mathrm{KOH}-\mathrm{KNO}_{3}$ salts amount $: 150 \mathrm{~g}$

$\mathrm{KNO}_{8}$ concentration : $15 \mathrm{~mol} \%$

Ore grain size : 150 170 mesh

Ore amount $: 2.5 \mathrm{~g}$, Temperature $: 220^{\circ} \mathrm{C}$

Agitation (rpm) -

$: 200, \bigcirc: 300, \quad: 400$

不 $2.5 \mathrm{~g}$ を $\mathrm{KOH}-\mathrm{KNO}_{3}$ 系溶融塩 $\left(\mathrm{KNO}_{3} 15\right.$ mol\%) $150 \mathrm{~g}$ に添 加し，220ㄷ においてかきませ速度を $200 ， 300 ， 400 \mathrm{rpm}$ に変 化させて反応を行なった結果を図 5 に示す。

反応速度はかきまぜ速度が $300 \mathrm{rpm}$ のとさに最大值そ示して いる。200 rpm では鉱石粒子の一部が反応器底に沈降し, また $400 \mathrm{rpm}$ ではかきまぜがはげしすぎるため鉱石粒子が反応器壁に 偏在し，そのため固・液の接触状態が悪くなって㧪散抵抗が生じ， 反応速度が小さくなるものと考えられる。

（4）鉱石粗度の影帮：粒径の異なるインド産鉣石 $2.5 \mathrm{~g}$ を $\mathrm{KOH}-\mathrm{KNO}_{3}$ 系溶融程 $\left(\mathrm{KNO}_{3} 15 \mathrm{~mol} \%\right) 150 \mathrm{~g}$ に添加し, 300 $\mathrm{rpm}, 220^{\circ} \mathrm{C}$ で反応させたときの結果を図 6 に示す。

鉱石は 150〜170，80〜100，50〜65 メッシュにそれぞれ粒度 調整したものを用いた。これら鈗石のマンガン含有率はつぎのと おりである。
150〜170 メッシュ
$\mathrm{MnO}_{2}=87.6 \%$
$80 \sim 100$
87.3
$50 \sim 65$
87.5

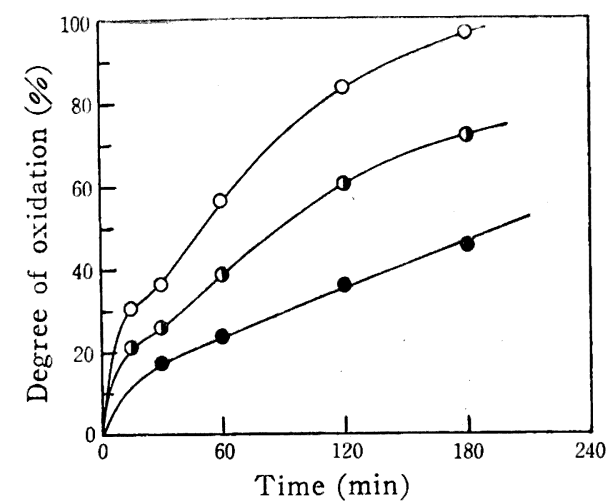

Fig. 6 Effect of ore grain size

$\mathrm{KOH}-\mathrm{KNO}_{3}$ salts amount : $150 \mathrm{~g}$

$\mathrm{KNO}_{3}$ concentration : $15 \mathrm{~mol} \%$

Ore amount : $2.5 \mathrm{~g}$, Temperature $: 220^{\circ} \mathrm{C}$

Agitation : $300 \mathrm{rpm}$

Ore grain size (mesh) -

$$
\bigcirc: 150 \sim 170, \quad \text { ( : 80 100, } \quad: 50 \sim 65
$$

マンガン含有率にはほとんど違いがないのでそれによる反応速 度への影響はないものとした。図 6 から反応速度は粒子が小さい ほど，すなわち鉱石の全表面積の大きい汪ど比例して大きくなっ ている。この結果については3.1.5で定量的に検討した。

以上の実験結果から，以後の温度の影響を調べるに最適と思わ れる条件をつぎのように決めた。

鉣 石 粒 径 150 170 メッシュ

鉱石添加量 溶融塩 $150 \mathrm{~g}$ に対し $2.5 \mathrm{~g}$

溶融塩組成 $\mathrm{KOH}: \mathrm{KNO}_{3}=85: 15(\mathrm{~mol})$

かきませ速度 $300 \mathrm{rpm}$

3.1.3 反応温度の影響：上に述べた実験条件で $200 \sim 240^{\circ} \mathrm{C} の$ 一定温度におけるマンガン酸化乷の変化を測定した結果を図 7 に 示す。

この結果から温度の反応速度におよぼす影響がかなり大きいこ とがわかる。いずれの場合もマンガン酸化率曲線は全体的に上に 凸型の曲線となったが，低温領域では反応初期に段状の曲線が現

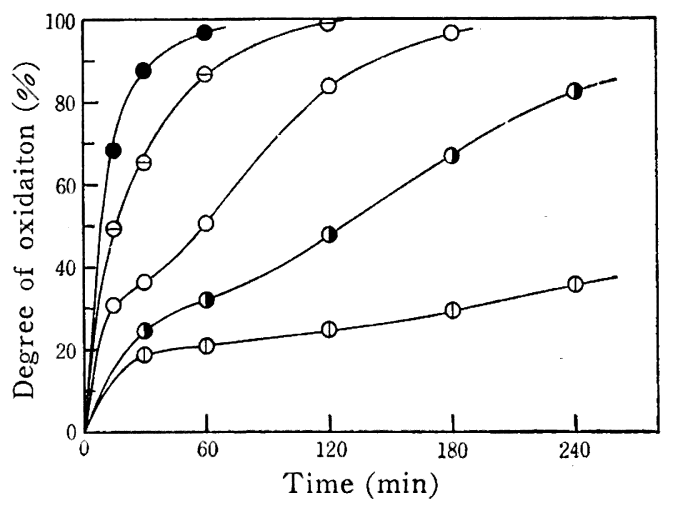

Fig. 7 Effect of temperature $\mathrm{KOH}-\mathrm{KNO}_{3}$ salts amount : $150 \mathrm{~g}$ $\mathrm{KNO}_{3}$ concentration : $15 \mathrm{~mol} \%$ Ore grain size : $150 \sim 170$ mesh Ore amount : $2.5 \mathrm{~g}$, Agitation : $300 \mathrm{rpm}$ Temperature $\left({ }^{\circ} \mathrm{C}\right)-$

(1) : 200, $: 210, \bigcirc: 220, \ominus: 230$, 
われる。これは反忘初期に一将的に鉱石の反応済固相部分が残り， これが反応速度に影響を与え，そののち反応の進行にともなって はく離していくためと考えられる。

マンガン鉱石はマンガン含有率が $\mathrm{MnO}_{2}$ 約 $88 \%$ と高く，乙 かもその結晶度が比较的覀いため反応の進行にともなって鉱石粒 子の径が次第に縮小していくのが観察された。

3.1.4 インド産釷石の反応速度：図７亿示す些騟絬果をュア・ モデルに罣づく反応速度式により恰討すると，各朋線は浴解型コ ア・モデルに拈ける化学反応律速の場合の式 ${ }^{11)}$ に比較的よく適合 することが判明した。

ただし，結果の解析にあたってつぎの仮定を設けた。

[仮定 A] 粒子(鉣石)は組成均一な球形である。

[仮定 B] 粒径は均一でその代表径はフルイ目盛りの算術平均 で表わされる。

[仮定 C］反応は粒子表面上り内部に向って進行するコア・モ デルにしたがう。

前に述べたかきまぜ速度の影響を調べた結果から，本実験では 粒子周辺の液膜内に拈ける反応物括よび生成物の拡散抵抗は無視 できると考えてよい。また反応の進行にともなって反応斉固相部 分がはがれ，粒子の径が減少していくことから，内部拡散の抵抗 も一応無視できるほど小さいと考えてよい。これらのことは四 7 の結果から, 温度の反応速度に拈よぼす影響がきわめて大きいこ とからも予想される。このような固・液系不均一反応に拈ける律 速段階としては化学反応のみが考えられる。

本実験結果を化学反応律速の場合の速度式に基づいて解析する と, $1-(1-x)^{1 / 3}$ 対 $t$ が因 8 亿示すように直線関係を構成し，各 温度ごとに実験結果は比較的よく整理される。このことは本分解 反応の律速段階が表面化学反応であることを意味する。

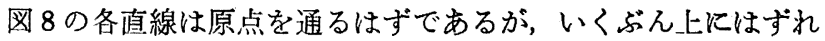
ているのは鉣石粒度が狭い範囲ながらも多少の分布を有し，細粒 部分がすみやかに反応するためと思われる。

反応の進行にともなって粒子径が縮小していく溶解型コア・モ

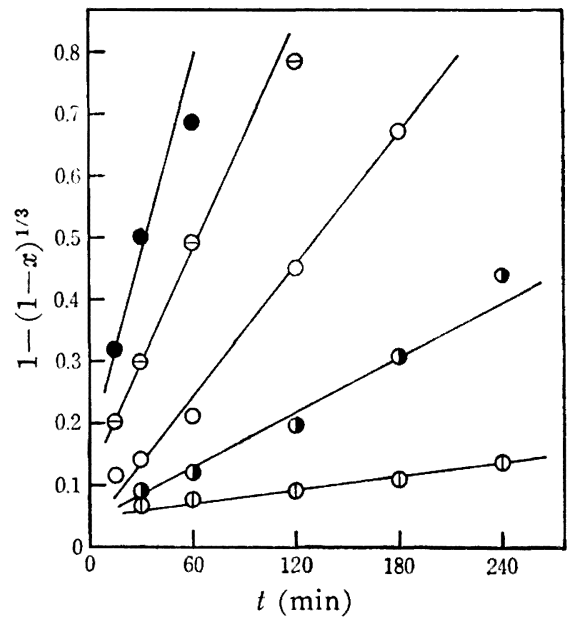

Fig. 8 Relationship between $1-(1-x)^{1 / 8}$ and reaction time, $t$

Temperature $\left({ }^{\circ} \mathrm{C}\right)$

$$
\text { (1) : } 200, \bigcirc: 210, \bigcirc: 220, \ominus: 230, \bigcirc: 240
$$

11）鍵谷 勤, “化学反応の速度論的研究法 (上)”, 化学同人 (1971) p. 397.
デルに持ける化学反応律速の場合の速度式および粒子の単位表面 積あたりの反応速度定数は（3）式で表わされる。

$$
1-(1-x)^{1 / 8}=\frac{k \cdot C \cdot t}{d_{\mathrm{s}} \cdot R}
$$

ただし， $x:$ 酸化率

$k:$ 単位表面積あたりの反応速度定数 $(\mathrm{cm} / \mathrm{min})$

$C:$ 液相中に持ける各反応成分の濃度 $\left(\mathrm{g} / \mathrm{cm}^{3}\right)$

$t:$ 反応時間 $(\mathrm{min})$

$d_{\mathrm{S}}:$ 粒子の密度 $\left(\mathrm{g} / \mathrm{cm}^{3}\right)$

$R:$ 粒子の半径 $(\mathrm{cm})$

本分解反応の場合, $C$ の内容は $\mathrm{KOH}$ 濃度括よび $\mathrm{KNO}_{3}$ 浱度 の効果であるが，これらは鉱石に対し十分多量に存在することか ら一定とみなすことができるので $k \cdot C=k_{0}$ とすれば（3）式は

$$
1-(1-x)^{1 / 3}=\frac{k_{0} \cdot t}{d_{\mathrm{S}} \cdot R}
$$

となる。

したがって, 図 8 の $1-(1-x)^{1 / 3}$ 対 $t$ の直線の傾きから各温度 に和ける $k_{0} / d_{\mathrm{S}} \cdot R$ の值が求まり，(4) 式から $k_{0}$ が算出される。 $d_{\mathrm{S}}=4.06 \mathrm{~g} / \mathrm{cm}^{3}, R=0.0048 \mathrm{~cm}$ として求めた $k_{0}$ の値を表 1 に示す。またこの $k_{0}$ を Arrhenius プロットして得た見かけ の活性化エネルギー $\left(E_{\mathrm{A}}\right)$ は

$$
E_{\mathrm{A}}=36 \mathrm{kcal} / \mathrm{mol}
$$

であった。

3.1.5 西アフリカ・ガボン産釷石の反応速度 : 150〜170 メッ シュに粒度調整したガボン産マンガン鉱石についてす前項と同様 な条件下で溶融カリウム塩との反応を行ない，同様な解析手法に よって反応速度定数执よび活性化エネルギーを求めた。鉱石のマ ンガン含有率は $\mathrm{MnO}_{2} 87.0 \%$ ，比重は 3.87 である。

ガボン産鉱石の場合も $200 \sim 240^{\circ} \mathrm{C}$ の温度条件では化学反応律 速のコア・モデルにしたがって進行するものとみることができ， 表 1 に示す反応速度定数および見かけの活性化エネルギーが得ら れた。

結局，本実験の条件においては跮石の産地によるマンガン含有 率や比重その他の若干の相違は溶融カリウム塩との反応の機構や 速度などにほとんど影響を拈よぼさないと見ることができる。

3.1.6 釷石粒度と反応速度の関連：前項（3.1.2）の鉱石粒度 の影智を調べた結果についてもこれまでと同样の手法により解析 し，鉣不の粒度により速度定数の変化の有無を検討した。本分解 反応が溶解型コア・モデルにおける化学反応に律速段階があると すれば，粒度の異なる鉝石を用いて反応を行なっても $k_{0}$ は変わ

\begin{tabular}{|c|c|c|c|}
\hline \multicolumn{2}{|c|}{ Ore } & India & Gabon \\
\hline \multicolumn{2}{|c|}{$\mathrm{MnO}_{2}$ content $(\%)$} & 87.6 & 87.0 \\
\hline \multicolumn{2}{|l|}{ Density } & 4.06 & 3. 84 \\
\hline \multirow{5}{*}{$\begin{array}{c}k_{0} \times 10^{5} \\
\left(\mathrm{~g} / \mathrm{cm}^{2} \cdot \mathrm{sec}\right)\end{array}$} & $200\left({ }^{\circ} \mathrm{C}\right)$ & 0.70 & 1. 45 \\
\hline & 210 & 2.54 & - \\
\hline & 220 & 6.85 & 6. 41 \\
\hline & 230 & 12.52 & - \\
\hline & 240 & 24.00 & 22.29 \\
\hline
\end{tabular}
らないはずである。

Table 1 Kinetic parameters of Indian and Gabonian ores 
Table 2 Kinetic parameters in several grain sizes of ore at $220^{\circ} \mathrm{C}$

\begin{tabular}{lccc} 
Ore grain size (mesh) & $50 \sim 65$ & $80 \sim 100$ & $150 \sim 170$ \\
\hline $\mathrm{MnO}_{2}$ content $(\%)$ & 87.5 & 87.3 & 87.6 \\
Density & 4.07 & 4.00 & 4.06 \\
$k_{0} \times 10^{5}\left(\mathrm{~g} / \mathrm{cm}^{2} \cdot \mathrm{sec}\right)$ & 4.40 & 6.31 & 6.85
\end{tabular}

得られた結果を表 2 に示したが，予想ど括り80〜100メッシュ と 150〜170 メッシュの場合の $k_{0}$ はよく一致した。 50 ６5 メッ シュの場合, かなり $k_{0}$ が小さくなったが, これは鉱石粒子が大 きすぎるために大部分反応器底に沈降し，拡散抵抗が生じたため と考えられる。

この結果から，本分解反応は溶解型コア・モデルで説明される 反応様式で進行し，鉱石表面ですみやかな物質移動をともないな がら反応済固相部分が順次はがれ，鈗石粒子は縮小していくもの と推定される。

\section{2 好適条件の探索}

3.2.1 アルカリ, 酸化剤添加量と反応温度の影響 : 速度論的 検討から（1）式に基づいて容易にマンガン（V)酸カリウムが生 成することがわかり，その反応悌式と反応速度が調べられた。

ここでは，マンガン( $\mathrm{V})$ 酸カリウムを中間体とするマンガンの オキソ酸カリウムの製造といら実用的な見地から，マンガン鉱 石の水酸化カリウム一硝酸カリウム系溶融塩処理によるマンガン (V)酸カリウム製造の好適条件を探索した。

条件の因子としては，アルカリモル比 $\left(\mathrm{KOH} / \mathrm{MnO}_{2}\right)$, 酸化剂 モル比 $\left(\mathrm{KNO}_{3} / \mathrm{MnO}_{2}\right)$ および反応温度をとり上げ, 表 3 に示すよ らにアルカリモル比 $=4 \sim 5$, 酸化剂モル比 $=0.5 \sim 2$, 反応温度 $250,300,350,400^{\circ} \mathrm{C}$ と変化させて実験を行なった。速度論的 実験と具体的に異なる点は, 鉱石添加量がかなり多くなったこと と鉱石をあらかじめ水酸化カリウム，硝酸カリウムとともに反応 器に入れてから昇温を開始したことである。また，すべての実験 を通じて総配合量は $150 \mathrm{~g}$ ，かきまぜ速度は $300 \mathrm{rpm}$ である。
以上の条件のもとで头験を行なった結果を表 3 と図 9,10 に示 す。 $250^{\circ} \mathrm{C}$ においては反応の進行は遅く、アルカリモル此と酸化 剤モル比が小さいと反応の途中でスラリー（融体）の粘椆化がみ られた。これは軟マンガン鉱の主成分である二酸化マンガンの酸 化速度が遅いと末反応の二酸化マシガンが膨潤することに起因し て扣り，このような状態になるとかきまぜによる均質なスラリー 状態がたもてなくなり反灾性・作業性はさわめて想くなる。した がって高い酸化率を得るためにはこのスラリ一の粘稠化胥避ける ことがもっとも必要となる。

温度を上げていくと， $280^{\circ} \mathrm{C}$ 付近で (1)式に基づく水の生成と 思われる発泡が見られ，反応は活発に進行し始める。

$300^{\circ} \mathrm{C}$ に拉ける実験ではマンガン酸化率はかなり高くなるが， 良好なスラリー状態をたもつためにはアルカリモル比 5 以上,

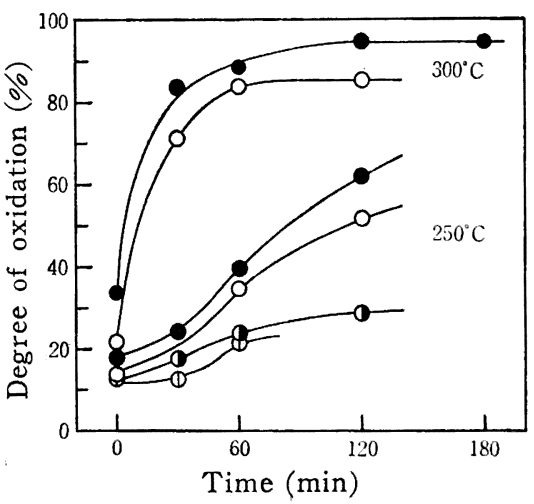

Fig. 9 Effect of alkali and nitrate molar ratio to $\mathrm{MnO}_{2}$ at 250 and $300^{\circ} \mathrm{C}$

Alkali - Nitrate molar ratio

$\begin{array}{ccc}\left(\mathrm{KOH} / \mathrm{MnO}_{2}\right) & (\mathrm{KNO} \\ 5 & - & 1 \\ 4 & - & 2 \\ 4 & - & 1 \\ 5 & - & 0.5\end{array}$

Table 3 Experimental results on oxidation of pyrolusite with molten salts

\begin{tabular}{|c|c|c|c|c|c|c|c|c|}
\hline \multirow{2}{*}{$\begin{array}{l}\text { Temperature } \\
\left({ }^{\circ} \mathrm{C}\right)\end{array}$} & \multicolumn{2}{|c|}{ Molar ratio } & \multicolumn{5}{|c|}{ Degree of oxidation $(\%)$ at time (min) } & \\
\hline & $\mathrm{KOH} / \mathrm{MnO}_{2}$ & $\mathrm{KNO}_{3} / \mathrm{MnO}_{2}$ & 0 & 30 & 60 & 120 & 180 & \\
\hline \multirow{6}{*}{250} & 4 & 0.5 & 12.0 & 18. 0 & 20.4 & - & - & $x$ \\
\hline & 4 & 1 & 12.6 & 17.6 & 23.8 & 28.8 & - & $\triangle$ \\
\hline & 4 & 2 & 13. 6 & - & 34.9 & 51.8 & - & $\overrightarrow{0}$ \\
\hline & 5 & 0.5 & 12.1 & 12.2 & 21.3 & - & - & 0 \\
\hline & 5 & 1 & 17.8 & 24.2 & 39.3 & 62.0 & - & 0 \\
\hline & 4 & 1 & 20.8 & 75.8 & - & - & - & $x$ \\
\hline \multirow{3}{*}{300} & 4 & 2 & 21.5 & 71.1 & 83.7 & 85.3 & - & 0 \\
\hline & 5 & 0.5 & 28. 2 & - & - & - & - & $x$ \\
\hline & 5 & 1 & 33.3 & 83.2 & 88.4 & 94.6 & 94.4 & 0 \\
\hline \multirow{4}{*}{350} & 4 & 1 & 65.7 & 75.5 & $\ldots$ & - & - & $x$ \\
\hline & 4 & 2 & 86.9 & 88.3 & 88.5 & 88.4 & - & 0 \\
\hline & 5 & 0.5 & 80.9 & 90.0 & 95.2 & 94.0 & - & $\times$ \\
\hline & 5 & 1 & - & 97,0 & 97.6 & 98.0 & - & 0 \\
\hline \multirow{5}{*}{400} & 4 & 1 & 82.2 & 87.4 & 88.4 & 90.1 & - & $x$ \\
\hline & 4 & 2 & 79.6 & 78.0 & 86.8 & 91.6 & 94.4 & $\triangle$ \\
\hline & 5 & 0.5 & 87.4 & - & - & - & - & $x$ \\
\hline & 5 & 1 & 84.4 & 91.7 & 89.6 & 89.3 & 89.1 & 0 \\
\hline & 5 & 2 & 95.3 & 92.7 & 90.4 & 95.3 & 93.4 & 0 \\
\hline
\end{tabular}




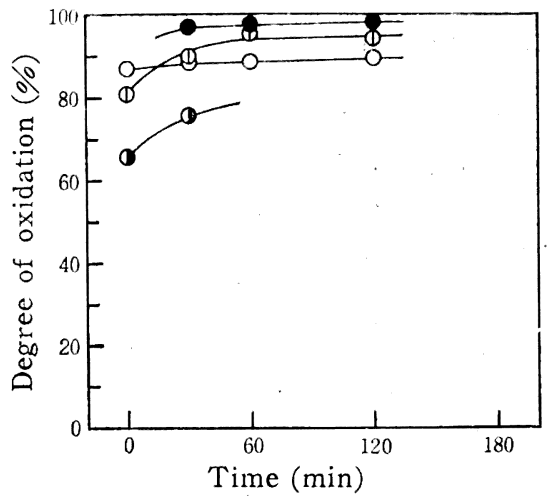

Fig. 10 Effect of alkali and nitrate molar ratio to $\mathrm{MnO}_{2}$ at $350^{\circ} \mathrm{C}$

Alkali - Nitrate molar ratio $\left(\mathrm{KOH} / \mathrm{MnO}_{2}\right) \quad\left(\mathrm{KNO}_{3} / \mathrm{MnO}_{2}\right)$

\begin{tabular}{|c|c|c|}
\hline & 5 & - \\
\hline O: & 4 & - \\
\hline (1) & 4 & - \\
\hline$\Theta:$ & 5 & - \\
\hline
\end{tabular}

酸化剂モル比 1 以上が必要であった。このことは高いマンガン 酸化率を得るには当量より過剩の水酸化カリウム，硝酸カリウム の存在が必須の要件の一つであることを示している。

$350^{\circ} \mathrm{C}$ では一層反応の進行が活発となり，上記の条件下ではほ とんど完全に反応が行なわれている。しかし，400 C では逆に若 干マンガン酸化率が低くなる。これは反応温度が高過ぎると生成 してくるマンガン $(\mathrm{V})$ 酸カリウムの一部が熱分解するためと考え られる。このことから，反応温度に関しては経済性も考虑して $350^{\circ} \mathrm{C}$ がもっともよい条件といえる。

また硝酸カリウムは酸化剤としての役割以外に融剤としても顕 著な作用を示している。たとえば，予備実験に怙いて酸化剤モル 比を（1）式の当量である 0.5 亿設定し，アルカリモル比を 5 以 上はるかに大きくしてもスラリーの粘稠化がみられた。

以上の結果から，マンガン鉱石の溶融カリウム塩処理によるマ ンガン $(\mathrm{V})$ 酸カリウム製造の好適条件は，鉱石の $\mathrm{MnO}_{2}$ 成分に対 するアルカリモル比 $=5$, 酸化㘊モル比 $=1$ ，加熱温度 $300 \sim 350$ ${ }^{\circ} \mathrm{C}$ ，加熱時間 1〜2 㭙間付近にあり，この条件下で $95 \%$ 程度の 高いマンガン酸化率が得られた。

3.2 .2 分解反応の経過: 本分解反応に执いて硝酸カリウムは 酸化刘として消費され，それ自体還元されて亜硝酸カリウムとし て存在するものと考学られるが，ここでは反応の進行とともに硝 酸塩が正硝酸塩に還元される過程をマンガン(V)酸カリウムの生 成すなわらマンガン酸化率と対比させて追跡してみた。

インド産マンガン鉱石に刘してアルカリモル比 $=5$, 酸化剂モ ル比=1となるように $\mathrm{KOH}-\mathrm{KNO}_{3}$ 系溶融堛を配合し, 温度 270 ${ }^{\circ} \mathrm{C}$ で加然処理して得た生成物について 5 仙、ンガン量とともに 2.3 で述べたデバルダ合金法により全窒素最, ザルッマン法によ り雨硝酸根の量を求めた。

3 侍間にわたって反応させた結果を図 11 に示す。このことか

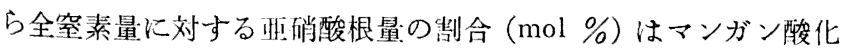

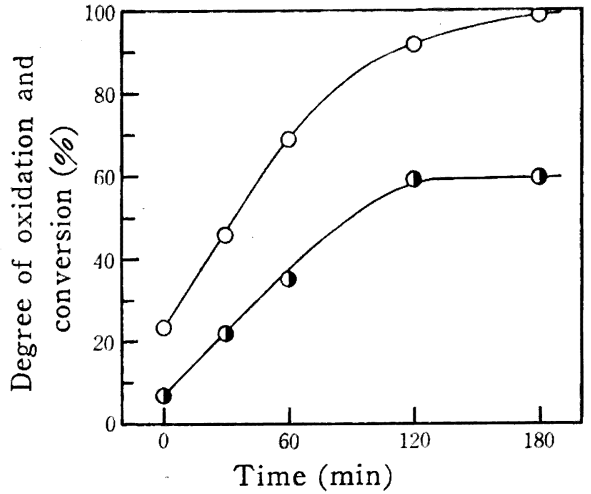

Fig. 11 Variation of degree of oxidation and conversion with time $\mathrm{KOH} / \mathrm{MnO}_{2}=5, \quad \mathrm{KNO}_{3} / \mathrm{MnO}_{2}=1$

Temperature : $270^{\circ} \mathrm{C}$

$\mathrm{O}$ : Degree of oxidation of pyrolusite

(1) Degree of conversion, $\mathrm{NO}_{2}^{-} / \mathrm{T} . \mathrm{N}$

率とほとんど対応して増大していることがわかる。この条件では (1)式にしたがえば硝酸カリウムの量は当量の 2 倍加えているの で，マンガン酸化率が $100 \%$ に近づくにつれて亜硝酸カリウムの 生成率は $50 \%$ に近づく。この結果から, 硝酸カリウムは鉱石中 の二酸化マンガンを酸化してそれ自体亜硝酸カリウムに還元され て存在することが明らかであり，以上の実験条件では（1）式は 定量的に進行することがわかる。

\section{4 結 論}

マソガン鉱石の水酸化カリウムと硝酸カリウムとの混合溶融塩 による処理に関してつぎの知見を得た。

（1）速度論的検討より, マンガン鉱石中の $\mathrm{MnO}_{2}$ 成分之溶 融カリウム塩とは比較的低温 $\left(200^{\circ} \mathrm{C}\right.$ 以上) においてつぎの反応 によってマンガン $(\mathrm{V})$ 酸カリウムを生成する。

$2 \mathrm{MnO}_{2}+6 \mathrm{KOH}+\mathrm{KNO}_{3}=2 \mathrm{~K}_{3} \mathrm{MnO}_{4}+\mathrm{KNO}_{2}+3 \mathrm{H}_{2} \mathrm{O}$

（2）本実験の条件における酸化率曲線はいずれも溶解型コ ア・モデルに打ける化学反応律速の昜合の式

$$
1-(1-x)^{1 / 8}=k t
$$

によく適合する。

（3） マンガン鈗石の産地，マンガン含有率，比重などの相違 は反応速度にほとんど影響を括よぼさず，インド産扣よび西アフ リカ・ガボン産鉱石は約 $32 \sim 36 \mathrm{kcal} / \mathrm{mol}$ の活性化エネルギーを 示す。

（4）実用的な好適条件は，鉱石中の $\mathrm{MnO}_{2}$ 成分に対するア ルカリモル比 $=5$, 酸化剂モル比 $=1$, 加與温度 $300 \sim 350^{\circ} \mathrm{C}$, 加熱 洔間 1〜2 㭙間付近にあり，この条件下で上式に基づいて 95。 程度のマンガン酸化率が得られる。

本研究を行な5にあたり種々の面で御援助をいただいた日本化 学工業株式会社に感謝の意を表する。

（1974 年 4 月，日本化学会第 30 春季年会講演） 


\title{
Oxidation of Pyrolusite by Molten Potassium Salts ${ }^{\dagger}$
}

\author{
Ei-ichi Narita*, Muneo Mita** and Taijiro OKaвE* \\ * Department of Applied Chemistry, Faculty of Engineering, \\ Tohoku University; Aramaki, Sendai-shi 980 Japan \\ *:* Nippon Chemical Industrial Co. Ltd. ; Kameido, \\ Koto-ku, Tokyo 136 Japan
}

The oxidation reaction of pyrolusite with $\mathrm{KOH}-\mathrm{KNO}_{3}$ molten salts for the preparation of potassium manganate $(\mathrm{V})$ has been studied in the temperature range of $200 \sim 240^{\circ} \mathrm{C}$.

$$
2 \mathrm{MnO}_{2}+6 \mathrm{KOH}+\mathrm{KNO}_{3}=2 \mathrm{~K}_{3} \mathrm{MnO}_{4}+\mathrm{KNO}_{2}+3 \mathrm{H}_{2} \mathrm{O}
$$

The grain sizes of pyrolusite ores were gradually reduced with the progress of oxidation reaction. The analysis of kinetic curves in terms of a core-model revealed that the chemical reaction on the unreacted core surface was the rate-determining step of the reaction and that the rate was expressed by the following equation,

$$
1-(1-x)^{1 / 3}=k t
$$

where $x$ was degree of oxidation of $\mathrm{MnO}_{2}, k$ was constant and $t$ was reaction time.

The apparent activation energies were found to be about $36 \mathrm{kcal} / \mathrm{mol}$ for Indian pyrolusite and $32 \mathrm{kcal} / \mathrm{mol}$ for Gabonian one.

The appropriate oxidation conditions of pyrolusite were investigated by treating it with $\mathrm{KOH}-\mathrm{KNO}_{3}$ molten salts under various conditions of alkali and nitrate molar ratio to $\mathrm{MnO}_{2}$, temperature $\left(250 \sim 400^{\circ} \mathrm{C}\right)$ and reaction time, and found that oxidation of pyrolusite proceeded most favorably at the following condition :

Alkali molar ratio : about 5 , Nitrate molar ratio : about 1 ,

Reaction temperature : $300 \sim 350^{\circ} \mathrm{C}$, Duration of reaction : $1 \sim 2 \mathrm{hrs}$.

About $95 \%$ of pyrolusite was oxidized at the condition.

$\dagger$ Studies on Manufacturing Process of Alkali Salts of Manganese Oxyacids. I. 